The Effect Locus of Control and Organizational Culture Toward Employee Performance with Organizational Commitments as Intervening Variable by Sitti Rizki Mulyani, Marta Widian Sari, Vivi Nila Sari, Winda Tawakalni

\title{
The Effect Locus of Control and Organizational Culture Toward Employee Performance with Organizational Commitments as Intervening Variable
}

\author{
Sitti Rizki Mulyani *) \\ Marta Widian Sari **) \\ Vivi Nila Sari ***) \\ Winda Tawakalni $* * * *)$
}

\begin{abstract}
This study aims to examine the influence of locus of control and organizational culture toward employee performance with organizational commitment as an intervening variable. The use of organizational commitment as a predictor in evaluating employee performances makes this research different from all other research. The source of data from this study was obtained from primary data by distributing questionnaires with sample size target is 141 employees. The analytical method used in this study is multiple regression analysis and path analysis. The results of this study indicate that there is a direct relationship between locus of control and organizational culture toward organizational commitment and employee performance. Also, there is an indirect effect between locus of control and organizational culture toward employee performance with organizational commitment as an intervening variable.
\end{abstract}

Keywords: Locus of Control; Organizational Culture; Organizational Commitment; Employee Performance

\section{INTRODUCTION}

\subsection{Research Background}

Every organization is required to be able to optimally manage its human resources. Employees are the main assets of the organization and have a strategic role in the organization, as thinkers, planners, and controllers of organizational activities. The vast development of the era has an impact on increasingly cut-throat economic competition. Organizations are required to continue to grow. Therefore, organizations need talent that can work professionally in accordance with the quality of their expertise. Quality human resources are one of the strengths owned by an organization to achieve organizational goals through the performance of the employees in the organization. The success of an organization in achieving its goals is strongly influenced by human resources as the driving force of various resources within an organization. In understanding the importance of human resources, organizations need to manage and empower employees so that productivity and performance of employees increases.

Performance is a result of work achieved by a person in carrying out his/her duties assigned to him based on skills, experience, and sincerity. There are several factors that influence employee performance like organizational resource, work engagement (Salanova, Agut, \& Peiró, 2005), organizational commitment (Chen \& Francesco, 2003; Joo, \& Bennett III, 2018; Verburg, Nienaber, Searle, Weibel, Den Hartog, \& Rupp, 2018; Chen, Tsui, \& Farh, 2002), recognition, reward (Wickramasinghe, \& Sajeevani, 2018, Gilbert, \& Kelloway, 2018), culture (Øgaard, Larsen, \& Marnburg , 2005; Munafis, Djamil, \& Walujadi, 2018; Ozcelik, \& Barsade, 2018; Suharto, \& Nusantoro, 2018), and locus of control (Howell, \& Avolio, 1993, Chen, \& Silverthorne, 2008, 
Khushk, 2019). This research only focuses on three factors in predicting employee performance, which is organizational culture, locus of control, and organizational commitment due to the reason that only those factors that matter in researchers object of research. The use of organizational commitment as a predictor in evaluating employee performances makes this research different from all other research.

\subsection{Research Problem}

Based on the background of the problem described above, the writer can formulate the problems in the research:

a) How is the direct effect of locus of control and organizational culture toward organizational commitment?

b) How is the direct effect of locus of control and organizational culture toward employee performance?

c) How is the indirect effect of locus of control and organizational culture toward employee performance with organizational commitment as an intervening variable?

\subsection{Research Purpose}

The purpose of this study can be described as follows:

a) To know and understand the direct effect of locus of control and organizational culture toward organizational commitment.

b) To know and understand the direct effect of locus of control and organizational culture toward employee performance.

c) To know and understand the indirect effect of locus of control and organizational culture toward employee performance with organizational commitment as an intervening variable.

\section{THEORETICAL FRAMEWORK AND HYPOTHESES DEVELOPMENT}

\subsection{Locus of Control}

Locus of control is a person's perspective on an event whether a person feels he/she can or cannot control the events that occur to him/her (Amalini, Al Musadieq, \& Afrianty, 2016). Locus of control can be divided into two characteristics which are an internal locus of control and external locus of control. While internal locus of control is the belief that someone can control events and consequences that affect a person's life. An external locus of control tends to concede important results in their lives to the causes in the environment. They wait for the external situation to come in his/her favor. Wahyuni, Taufik, \& Ratnawati (2016) added that individual with an external locus of control beliefs that failures experienced by individuals is due to unluckiness, far-reaching planning of futile work, events experienced in life that are determined by people in power, individuals success due to fate. Contradictory, individual with internal locus of control beliefs that everything is achieved by individuals by the results of their efforts, being leaders because of their abilities, individuals success due to hard work, everything obtained by individuals not based on luck, individuals ability to determine events in life, individuals life determined by actions, failures experienced by individuals due to their own actions. Therefore, an employee with an internal locus of control characteristic has more work spirit and successful career than the others (Saputra, 2014). Similiarly, Chen, \& Silverthorne (2008) states that individuals with a higher internal locus of control tend to have higher levels of job performance and satisfaction. Khushk (2019) added that in term of the locus of control effect toward organizational commitment, an employee with an internal locus of control beliefs that organizational commitment plays a crucial role in employee 
performance while an employee with external locus control tend to ignore the importance of organizational commitment to their work achievement.

\subsection{Organizational Culture}

Dai, Chan, \& Yee (2018) defines organizational culture as organizational culture is unique characteristics that reflect an organization's goals and values, including assumptions, beliefs, norms, and ideas. Kangas, Kaptein, Huhtala, Lämsä, Pihlajasaari, \& Feldt (2018) added that organizational culture is the ethical quality of a work environment, incorporating the experiences, presumptions, and expectations of the organization's members. Marliana (2015) concluded that organizational culture is an organizational value system adopted by members of the organization, which influences the way of working and behaving from the members of the organization. Culture is defined as the way of life of people inherited from generation to generation through various learning processes to create a certain life that best fits the environment. Culture is a pattern of shared basic assumptions that groups learn through solving problems of external adaptation and internal integration. Research from Øgaard, Larsen, \& Marnburg (2005) concluded that there is relationship between culture and organizational commitment. Jufnidar \& Ma'arif (2018) also added that culture also has a positive effect toward employee performance, commitment, and job satisfaction.

\subsection{Organizational Commitment}

Mowday, Steers, \& Porter (1979) defines organizational commitment as the strong desire of the individual to become a member of an organization by involving themselves wholeheartedly to accomplished organization goals. While Khushk (2019) defines organizational commitment as employee involvement and membership in an organization. Chen \& Francesco (2003) classified organizational citizen commitment behavior into three categories, namely affective commitment, normative commitment, and continuance commitment. Pardiman (2018) argues that when an individual has a common goal with organization, they motivated to work hard to realize an organizational goal. Therefore, the higher motivation of employee the more good performance achieved (Yeh, \& Hong, 2012).

\subsection{Employee performance}

According to Melayu SP Hasibuan in Mulyadi (2015), performance (achievement) is a result of work achieved by a person in carrying out his/her duties assigned to him/her based on the skills, experience, and sincerity. While Karakas (2010) define employee performance as individuals work achievement after exerting effort on the job though compassionate other colleagues. Nurcahyani \& Adnyani (2016) added that employee performance is the employee work result in term of quantity and quality for the job assigned to them. Budiono (2016) stated that the indicators of employee performance are the ability to cooperate, quality of work, technical capability, initiative, enthusiasm, endurance, the quantity of work

Therefore, the hypotheses proposed in this study are;

$\mathrm{H}_{1}$ : The locus of control and organizational culture has directly affect organizational commitment.

$\mathrm{H}_{2}$ : The locus of control and organizational culture has directly affect employee performance.

$\mathrm{H}_{3}$ : The locus of control and organizational culture have an indirect influence toward employee performance with organizational commitment as an intervening variable. 


\section{RESEARCH METHOD}

\subsection{Research Design}

This study can be classified as quantitative explanatory research. The data used in this study were primary data conducted by questionnaire survey. To investigate the relationship of variable, this research uses regression and path analysis with the help of SPSS software and Sobel calculator to measure the direct and indirect effect.

\subsection{Population and Sample}

The population in this study is all 218 employees of one crumb rubber factory in West Sumatera, Indonesia. The reason in choosing one of the rubber companies in Indonesia as research object is due to the reason that those company has not operated their production effectively and efficiently. This study used the Slovin formula to determine the sample size that obtained 141 employees. The simple random sampling used as a sampling technique

\subsection{Research Framework}

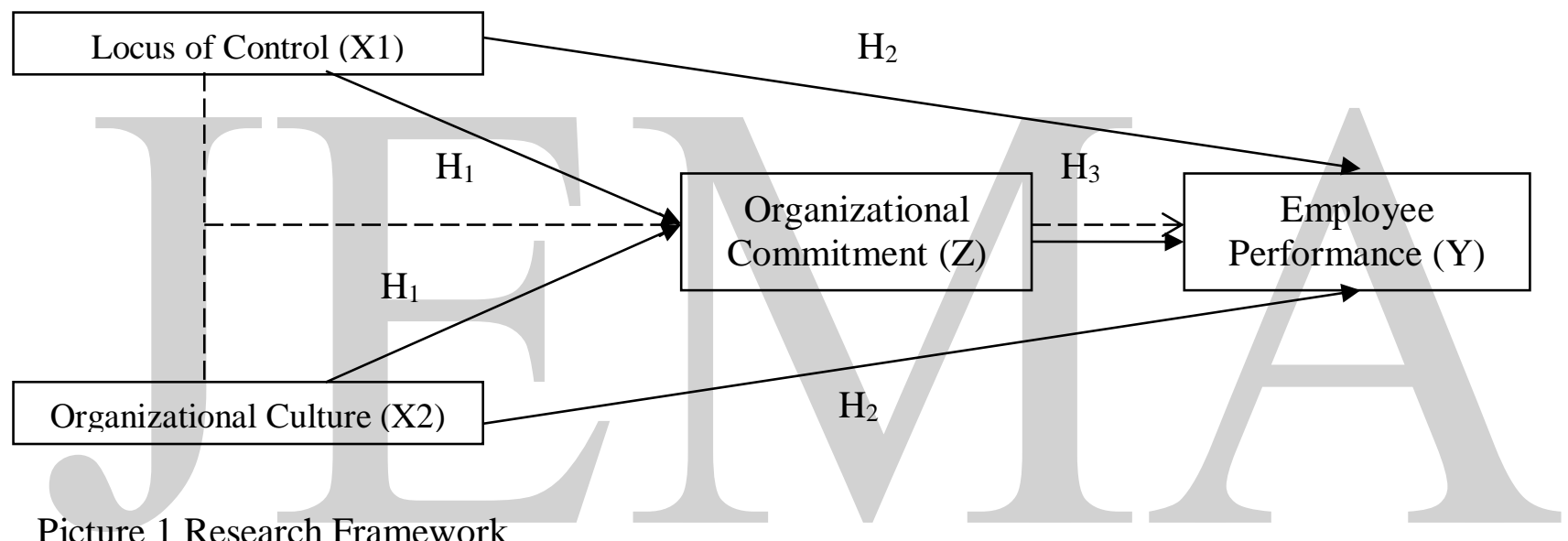

Picture 1 Research Framework

\section{RESEARCH RESULT AND ANALYSIS}

\subsection{Descriptive Analysis}

Table 1 Profile of Respondent

\begin{tabular}{|c|c|c|}
\hline Information & Total & Percentage $(\%)$ \\
\hline \multicolumn{3}{|l|}{ Sex } \\
\hline Male & 115 & 81,6 \\
\hline Female & 26 & 18,4 \\
\hline \multicolumn{3}{|l|}{ Age } \\
\hline$\leq 20-29$ years old & 40 & 28,4 \\
\hline $30-39$ years old & 69 & 48,9 \\
\hline$\geq 40$ years old & 32 & 22,7 \\
\hline \multicolumn{3}{|l|}{ Level of Education } \\
\hline High School & 105 & 74,5 \\
\hline Diploma & 17 & 12 \\
\hline Bachelor & 19 & 13,5 \\
\hline
\end{tabular}

Source: Primary Data Processed, 2019 
JEMA: Jurnal Ilmiah Bidang Akuntansi dan Manajemen, Vol. 16 No. 2 (2019) http://riset.unisma.ac.id/index.php/jema (e-ISSN : 2597-4071)

Majority of the respondent in this study is male with a range of ages between 30-39 years old and the high school graduated. There is no different respond between respondents regarding their commitment and performance from gender (sex), distribution of ages, and level of education point of view. Profile of respondents in the study is presented in Table 1.

\subsection{Validity and Reliability}

Table 2 Validity Result

\begin{tabular}{|c|c|c|c|c|}
\hline \multirow{2}{*}{ Variable } & \multirow{2}{*}{ Item } & r-test & r-statistic 5\% & \multirow{2}{*}{ Decision } \\
\hline & & $\mathrm{N}=141$ & Df (N-2) 139 & \\
\hline \multirow{10}{*}{$\begin{array}{l}\text { Locus Of Control } \\
\text { (X1) }\end{array}$} & 1 & 0,621 & 0,165 & Valid \\
\hline & 2 & 0,706 & 0,165 & Valid \\
\hline & 3 & 0,636 & 0,165 & Valid \\
\hline & 4 & 0,899 & 0,165 & Valid \\
\hline & 5 & 0,556 & 0,165 & Valid \\
\hline & 6 & 0,899 & 0,165 & Valid \\
\hline & 7 & 0,728 & 0,165 & Valid \\
\hline & 8 & 0,573 & 0,165 & Valid \\
\hline & 9 & 0,899 & 0,165 & Valid \\
\hline & 10 & 0,899 & 0,165 & Valid \\
\hline \multirow{10}{*}{$\begin{array}{l}\text { Organizational } \\
\text { Culture (X2) }\end{array}$} & 1 & 0,709 & 0,165 & Valid \\
\hline & 2 & 0,926 & 0,165 & Valid \\
\hline & 3 & 0,969 & 0,165 & Valid \\
\hline & 4 & 0,883 & 0,165 & Valid \\
\hline & 5 & 0,524 & $\begin{array}{r}0,165 \\
\end{array}$ & Valid \\
\hline & 6 & 0,709 & 0,165 & Valid \\
\hline & 7 & 0,926 & 0,165 & Valid \\
\hline & 8 & 0,969 & 0,165 & Valid \\
\hline & 9 & 0,883 & 0,165 & Valid \\
\hline & 10 & 0,524 & 0,165 & Valid \\
\hline \multirow{10}{*}{$\begin{array}{c}\text { Organizational } \\
\text { Commitment }(\mathrm{Z})\end{array}$} & 1 & 0,918 & 0,165 & Valid \\
\hline & 2 & 0,921 & 0,165 & Valid \\
\hline & 3 & 0,986 & 0,165 & Valid \\
\hline & 4 & 0,957 & 0,165 & Valid \\
\hline & 5 & 0,661 & 0,165 & Valid \\
\hline & 6 & 0,831 & 0,165 & Valid \\
\hline & 7 & 0,918 & 0,165 & Valid \\
\hline & 8 & 0,921 & 0,165 & Valid \\
\hline & 9 & 0,986 & 0,165 & Valid \\
\hline & 10 & 0,957 & 0,165 & Valid \\
\hline
\end{tabular}


JEMA: Jurnal Ilmiah Bidang Akuntansi dan Manajemen, Vol. 16 No. 2 (2019) http://riset.unisma.ac.id/index.php/jema (e-ISSN : 2597-4071)

\begin{tabular}{|c|c|c|c|c|}
\hline \multirow{3}{*}{ Variable } & \multirow{2}{*}{ Item } & r-test & r-statistic 5\% & \multirow{2}{*}{ Decision } \\
\cline { 2 - 5 } & $\mathrm{N}=141$ & $\mathrm{Df}(\mathrm{N}-2) 139$ & \\
\hline 1 & 0,637 & 0,165 & Valid \\
\cline { 2 - 5 } & 2 & 0,671 & 0,165 & Valid \\
\cline { 2 - 5 } & 3 & 0,434 & 0,165 & Valid \\
\cline { 2 - 5 } & 4 & 0,533 & 0,165 & Valid \\
\cline { 2 - 5 } Employee & 5 & 0,671 & 0,165 & Valid \\
\cline { 2 - 5 } & 6 & 0,831 & 0,165 & Valid \\
\cline { 2 - 5 } & 7 & 0,831 & 0,165 & Valid \\
\cline { 2 - 5 } & 8 & 0,755 & 0,165 & Valid \\
\cline { 2 - 5 } & 9 & 0,811 & 0,165 & Valid \\
\cline { 2 - 5 } & 10 & 0,831 & 0,165 & Valid \\
\cline { 2 - 5 } & 11 & 0,755 & 0,165 & Valid \\
\cline { 2 - 5 } & 12 & 0,759 & 0,165 & Valid \\
\cline { 2 - 5 } & 13 & 0,831 & 0,165 & Valid \\
\cline { 2 - 5 } & 14 & 0,755 & 0,165 & Valid \\
\cline { 2 - 5 } & 15 & 0,759 & 0,165 & Valid \\
\hline \multirow{7}{*}{\begin{tabular}{l} 
Permance (Y) \\
\cline { 2 - 5 }
\end{tabular}} & & & \\
\hline
\end{tabular}

Source: Primary Data Processed, 2019

Table 3 Reliability Result

\begin{tabular}{|c|c|c|c|c|}
\hline \multirow{2}{*}{ Variable } & \multicolumn{2}{|c|}{$\mathrm{N}=141$} & \multirow{2}{*}{ Rule of Thumb } & \multirow{2}{*}{ Decision } \\
\cline { 2 - 5 } & Item & Cronbach Alpha & & Reliable \\
\hline Locus of Control & 10 & 0,920 & 0,5 & Reliable \\
\hline Organizational Culture & 10 & 0,953 & 0,5 & Reliable \\
\hline Employee Performance & 15 & 0,944 & 0,5 & Reliable \\
\hline Organizational Commitment & 10 & 0,979 & 0,5 & \\
\hline
\end{tabular}

Source: Primary Data Processed, 2019

Based on both tables, it can be concluded that all items and variables in this research are valid and reliable.

\subsection{Research Analysis}

A good regression model must have no symptoms of heteroskedasticity, autocorrelation, multicollinearity, and normal distribution. The classical assumption testing can be seen below. 


\section{a. Normality Test}

From the table 4, the normality test shows Asymp. Sig (2-tailed) is higher than 0,05, which is 0,107 . This means that the data is normally distributed so that it is appropriate to be used for multiple regression analysis.

Table 4 One-Sample Kolmogorov-Smirnov Test

\begin{tabular}{|l|l|r|}
\hline \multicolumn{2}{|c|}{ Description } & Unstandardized Residual \\
\hline $\mathrm{N}$ & Mean & 141 \\
\cline { 2 - 3 } & Std. Deviation &, 0000000 \\
\hline \multirow{2}{*}{ Mormal Parameters } & a,b & 5,27990228 \\
& Absolute & 0,102 \\
\cline { 2 - 3 } & Positive & 0,059 \\
\cline { 2 - 3 } & Negative & $-0,102$ \\
\hline Kolmogorov-Smirnov Z & 1,211 \\
\hline Asymp. Sig. (2-tailed) & 0,107 \\
\hline
\end{tabular}

Source: Primary Data Processed, 2019

b. Multicollinearity Test

From the table 5, it can be seen that all tolerance values $>0,10$ and the VIF value $<10$, it means that there are no symptoms of multicollinearity between independent variables. Thus it can be concluded that the regression equation used as a prediction in this study is free from classical assumptions.

Table 5 Multicollinearity Test

\begin{tabular}{|l|c|c|}
\hline \multirow{2}{*}{\multicolumn{1}{|c|}{ Model }} & \multicolumn{2}{|c|}{ Collinearity Statistics } \\
\cline { 2 - 3 } & Tolerance & VIF \\
\hline (Constant) & & 1,130 \\
\hline Organizational culture & 0,885 & 1,025 \\
\hline Employee performance & 0,976 & 1,153 \\
\hline Organizational commitment & 0,867 & \\
\hline
\end{tabular}

Source: Primary Data Processed, 2019

\section{c. Heteroscedasticity Test}

From Picture 2 it can be seen that there is no heteroscedasticity in the regression model because there is no clear pattern and the points spread above and below the number 0 on the $\mathrm{Y}$-axis. So that it can be said that the heteroscedasticity test is fulfilled. 
Scatterplot

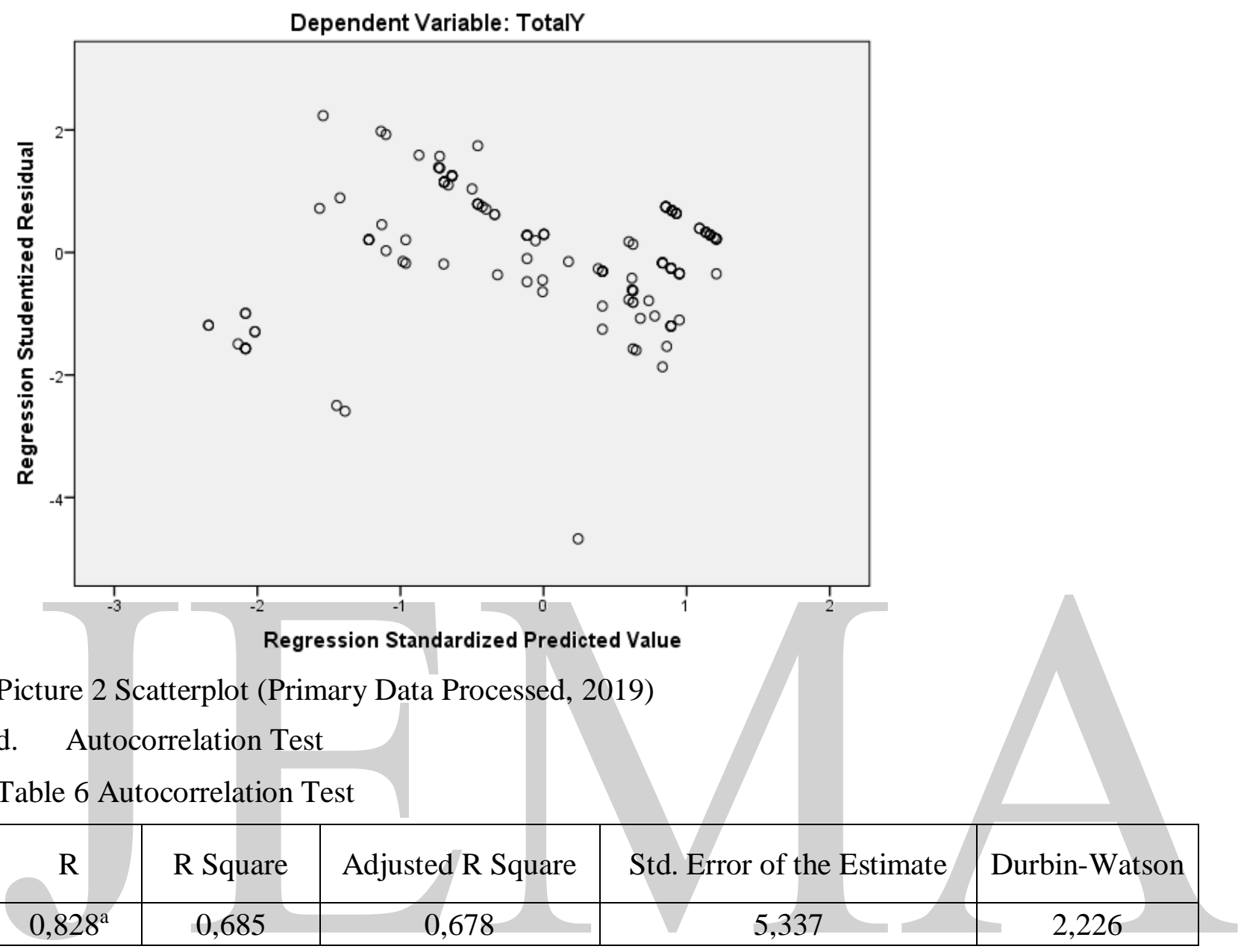

Source: Primary Data Processed, 2019

From the table 6 , it can be seen that the $\mathrm{D}-\mathrm{W}$ value obtained is 2,226 . The number is close between -2 to +2 . This means that the regression model does not have an autocorrelation problem.

Table 7 Regression Model 1 Result

\begin{tabular}{|l|r|r|r|r|r|}
\hline \multirow{2}{*}{ Model } & \multicolumn{2}{|c|}{$\begin{array}{c}\text { Unstandardized } \\
\text { Coefficients }\end{array}$} & $\begin{array}{l}\text { Standardized } \\
\text { Coefficients }\end{array}$ & \multirow{2}{*}{ T } & \multirow{2}{*}{ Sig. } \\
\cline { 2 - 4 } & \multicolumn{1}{|c|}{ B } & Std. Error & \multicolumn{1}{c|}{ Beta } & & \\
\hline (Constant) & 18,702 & 5,265 & & 3,552 & 0,001 \\
\hline Locus of Control & 0,433 & 0,102 & 0,336 & 4,240 & 0,000 \\
\hline Organizational culture & 0,163 & 0,089 & 0,146 & 1,843 & 0,067 \\
\hline
\end{tabular}

Source: Primary Data Processed, 2019

The regression test shows that the significance value between locus of control and organizational commitment is below 0,05 . So it can be concluded that locus of control has a significant effect on organizational commitment. Meanwhile, the significance value between organizational culture and organizational commitment is above 0,05 ; it indicates that organizational culture does not have a significant effect on organizational commitment. 
JEMA: Jurnal Ilmiah Bidang Akuntansi dan Manajemen, Vol. 16 No. 2 (2019)

http://riset.unisma.ac.id/index.php/jema (e-ISSN : 2597-4071)

Table 8 Regression Model 2 Result

\begin{tabular}{|c|c|c|c|c|c|}
\hline \multirow[t]{2}{*}{ Model } & \multicolumn{2}{|c|}{$\begin{array}{c}\text { Unstandardized } \\
\text { Coefficients }\end{array}$} & $\begin{array}{l}\text { Standardized } \\
\text { Coefficients }\end{array}$ & \multirow[t]{2}{*}{$\mathrm{T}$} & \multirow[t]{2}{*}{ Sig. } \\
\hline & B & Std. Error & Beta & & \\
\hline (Constant) & 18,530 & 2,892 & & 6,408 & 0,000 \\
\hline Locus of Control & 0,671 & 0,057 & 0,599 & 11,755 & 0,000 \\
\hline Organizational Culture & 0,115 & 0,047 & 0,118 & 2,435 & 0,016 \\
\hline Organizational Commitment & 0,334 & 0,045 & 0,384 & 7,468 & 0,000 \\
\hline
\end{tabular}

Source: Primary Data Processed, 2019

Based on the results of the regression test, it is shown that the significance value between locus of control, organizational culture, organizational commitment with the employee performance is below 0,05 . So that it can be concluded that locus of control, organizational culture, and organizational commitment has a significant effect on employee performance.

Table 9 Sobel Test

\begin{tabular}{|c|c|c|}
\hline Variable & Sobel Test Score & P-Value \\
\hline X1-Z-Y & $6,278,458$ & 0,000 \\
\hline X2-Z-Y & $2,323,795$ & 0,020 \\
\hline
\end{tabular}

Source: Primary Data Processed, 2019

Based on the results of the Sobel test, it can be concluded that there is an indirect effect between locus of control and organizational culture on employee performance through organizational commitment as the intervening variable (a significance value below 0,05 ).

\subsection{Research Discussion}

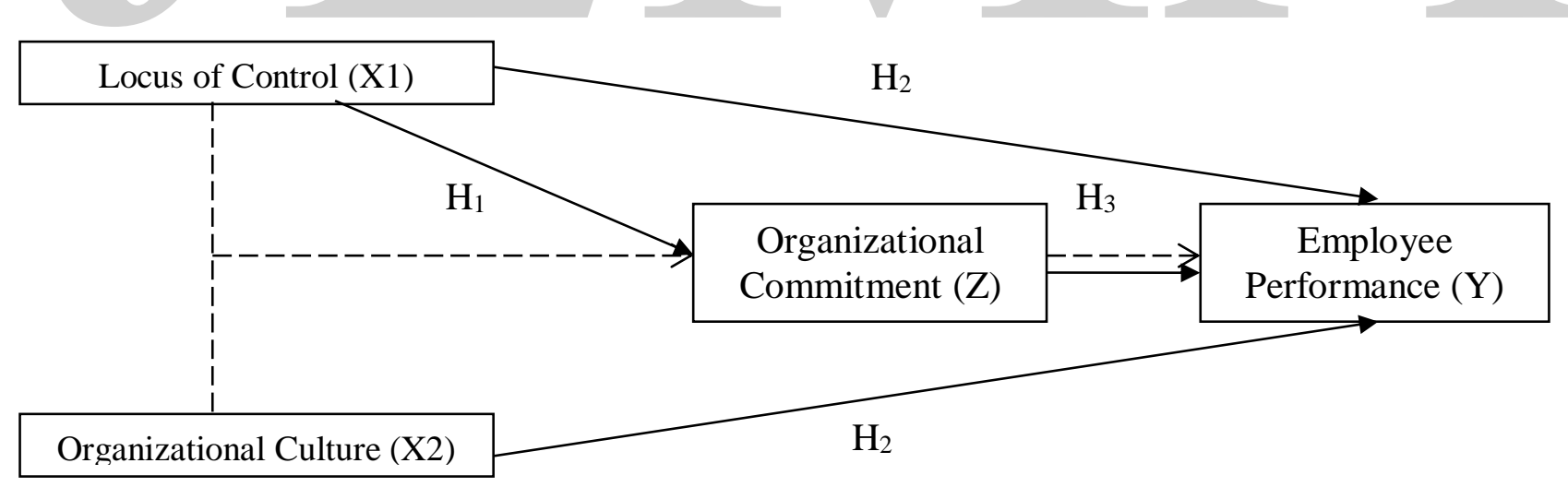

Picture 3 Research Result

This research result support previous research from Saputra (2014), Chen, \& Silverthorne (2008), Pardiman (2018), Yeh, \& Hong (2012) that states there is direct effect between locus of control and employee performances and organizational commitment (Khushk, 2019). This research also supports Jufnidar, \& Ma'arif (2018) argument that states culture has a positive effect toward employee performance. Unfortunately, this research failed to prove Øgaard, Larsen, \& Marnburg (2005) argument that states there is a relationship between culture and organizational commitment. 
This result indicates that employee prefers to do a job in freedom way than being compelled to do it rigidly so while organizational try to build and maintain strong culture, they also need to be flexible. Sunarsih \& Mashithoh (2016) argues that the insignificant relationship between organizational culture and commitment indicates that the company culture is not adaptive to growth and development within an organization. Finally, this study also succeeded in proving that there is an indirect influence between locus of control and organizational culture toward employee performance with organizational commitment as an intervening variable.

\section{RESEARCH CONCLUSION AND LIMITATION}

\subsection{Conclusion}

Based on the results of the hypotheses tests that have been done, it can be concluded that locus of control has a positive and significant direct effect toward organizational commitment. Locus of control, organizational culture, and organizational commitment partially also have a positive and significant direct effect toward employees of performance. This study also succeeded in proving that there is an indirect influence between locus of control and organizational culture on employee performance through the intervening of organizational commitment. Unfortunately, this research failed to prove the relationship between organizational culture and commitment. This result indicates that employee prefers to do a job in freedom way than being compelled to do it rigidly.

\subsection{Limitation}

Due to time constraints, the researcher had limited time in developing this research. For the next researcher, it is expected to further develop the results of this study and include relevant variables related to organizational commitment and employee performance in the hope that the results of the research to be more accurate and have far greater benefits so that the company can improve and develop human resources in the future years.

\section{REFERENCES}

Amalini, H. F., Al Musadieq, M., \& Afrianty, T. W. (2016). Pengaruh Locus of control terhadap kepuasan kerja dan kinerja (studi pada karyawan Perusahaan Daerah Air Minum (PDAM) Kota Malang). Jurnal Administrasi Bisnis, 35(1), 68-77.

Budiono, D. S. (2016). Pengaruh Budaya Organisasi Terhadap Kinerja Karyawan Melalui Komitmen Organisasi sebagai Variabel Intervening pada PT. Kerta Rajasa Raya. Jurnal Riset Ekonomi dan Manajemen, 16(1), 29-43. http://dx.doi.org/10.17970/jrem.16.160103.ID.

Chen, J. C., \& Silverthorne, C. (2008). The impact of locus of control on job stress, job performance and job satisfaction in Taiwan. Leadership \& Organization Development Journal, 29(7), 572-582. https://doi.org/10.1108/01437730810906326.

Chen, Z. X., \& Francesco, A. M. (2003). The relationship between the three components of commitment and employee performance in China. Journal of vocational behavior, 62(3), 490510. https://doi.org/10.1016/S0001-8791(02)00064-7.

Chen, Z. X., Tsui, A. S., \& Farh, J. L. (2002). Loyalty to supervisor vs. organizational commitment: Relationships to employee performance in China. Journal of occupational and organizational psychology, 75(3), 339-356. https://doi.org/10.1348/096317902320369749.

Dai, J., Chan, H. K., \& Yee, R. W. (2018). Examining moderating effect of organizational culture 
on the relationship between market pressure and corporate environmental strategy. Industrial Marketing Management, 74, 227-236. https://doi.org/10.1016/j.indmarman.2018.05.003.

Gilbert, S. L., \& Kelloway, E. K. (2018). Leadership, Recognition and Well-Being: A Moderated Mediational Model. Canadian Journal of Administrative Sciences/Revue Canadienne des Sciences de l'Administration, 35(4), 523-534. https://doi.org/10.1002/cjas.1477.

Howell, J. M., \& Avolio, B. J. (1993). Transformational leadership, transactional leadership, locus of control, and support for innovation: Key predictors of consolidated-business-unit performance. Journal of applied psychology, 78(6), 891. Retrieved from https://psycnet.apa.org/doiLanding?doi=10.1037\%2F0021-9010.78.6.891.

Joo, B. K. B., \& Bennett III, R. H. (2018). The Influence of Proactivity on Creative Behavior, Organizational Commitment, and Job Performance: Evidence from a Korean Multinational. Journal of International \& Interdisciplinary Business Research, 5(1), 1-20.

Jufnidar, J., \& Ma'arif, S. (2018). Pengaruh budaya organisasi, komitmen organisasi dan kepuasan kerja terhadap kinerja (studi kasus di PT. Cahaya Internusa Group Indonesia). Jurnal Riset Perbankan Manajemen dan Akuntansi, 2(2), 109-122. Retrieved from http://www.jrpma.spsperbanas.ac.id/index.php/jrpma/article/view/33.

Kangas, M., Kaptein, M., Huhtala, M., Lämsä, A. M., Pihlajasaari, P., \& Feldt, T. (2018). Why do managers leave their organization? Investigating the role of ethical organizational culture in managerial turnover. Journal of Business Ethics, 153(3), 707-723. https://doi.org/10.1007/s10551-016-3363-8.

Karakas, F. (2010). Spirituality and performance in organizations: A literature review. Journal of business ethics, 94(1), 89-106. https://doi.org/10.1007/s10551-009-0251-5.

Khushk, A. A. (2019). Impact of Locus of Control (LOC) and Organizational Commitment on Employee Performance-Study of Service Sector, Pakistan. Retrieved from https://www.researchgate.net/profile/Amir_Ali48/publication/332835100_Impact_of_Locus_ of_Control_LOC_and_Organizational_Commitment_on_Employee_PerformanceStudy_of_Service_Sector_Pakistan/links/5ccc22b192851c4eab7eb249/Impact-of-Locus-ofControl-LOC-and-Organizational-Commitment-on-Employee-Performance-Study-of-ServiceSector-Pakistan.pdf.

Marliana, R. (2015). Psikologi Industri dan Organisasi. Bandung: CV Pustaka Setia.

Mowday, R. T., Steers, R. M., \& Porter, L. W. (1979). The measurement of organizational commitment. Journal of vocational behavior, 14(2), 224-247. https://doi.org/10.1016/00018791(79)90072-1.

Mulyadi. (2015). Manajemen Sumber Daya Manusia (MSDM). Bogor: iN MEDIA.

Munafis, S., Djamil, M., \& Walujadi, D. (2018). Leaderships Style, Organization Culture on the Organizational Job Satisfaction in Improving Employee's Perfomance. A Study at The Center for Plant Conservation at the Bogor Botanical Garden. Jurnal Manajemen, 7(1), 69-80. http://dx.doi.org/10.32832/jm-uika.v7i1.730.

Nurcahyani, N. M., \& Adnyani, I. D. (2016). Pengaruh kompensasi dan motivasi terhadap kinerja karyawan dengan kepuasan kerja sebagai variabel intervening. E-Jurnal Manajemen $\begin{array}{llll}\text { Universitas } & \text { Sdayana, } & \text { Retrieved }\end{array}$ 
https://ojs.unud.ac.id/index.php/Manajemen/article/view/16159.

Øgaard, T., Larsen, S., \& Marnburg, E. (2005). Organizational culture and performance-evidence from the fast food restaurant industry. Food Service Technology, 5(1), 23-34. https://doi.org/10.1111/j.1471-5740.2005.00109.x.

Ozcelik, H., \& Barsade, S. G. (2018). No Employee an Island: Workplace Loneliness and Job Performance. Academy of Management Journal, 61(6), 2343-2366. https://https:/doi.org/10.5465/amj.2015.1066.

Pardiman, P. (2018). THE EFFECT OF SOCIAL CAPITAL AND ORGANIZATIONAL COMMITMENT TOWARD LECTURER PERFORMANCE WITH ISLAMIC WORK ETHICS AS A MODERATING ROLE. JEMA: Jurnal Ilmiah Bidang Akuntansi dan Manajemen, 15(01), 12-26. http://dx.doi.org/10.31106/jema.v15i01.779.

Salanova, M., Agut, S., \& Peiró, J. M. (2005). Linking organizational resources and work engagement to employee performance and customer loyalty: the mediation of service climate. Journal of applied Psychology, 90(6), 1217. https://psycnet.apa.org/doi/10.1037/00219010.90.6.1217.

Saputra, K. A. K. (2014). Pengaruh Locus of Control terhadap Kinerja dan Kepuasan Kerja Internal Auditor dengan Kultur Lokal Tri Hita Karana sebagai Variabel Moderasi. Jurnal Akuntansi Multiparadigma, 3(1), 86-100. http://dx.doi.org/10.18202/jamal.2012.04.7146.

Suharto, S., \& Nusantoro, J. (2018). The Relationship Among Managerial Capability, Organizational Citizenship Behavior, And Employee Performance: Mediation Effects Of Organizational Culture. Journal of Community Research and Service, 2(1), 168-175. https://doi.org/10.24114/jcrs.v2i1.9890.

Sunarsih, N., \& Mashithoh, H. (2016). The Influence of Organizational Culture Adaptability in Regard to the Organizational Commitment of the Staff of Universitas Terbuka. Review of Integrative Business and Economics Research, 5(1), 199-209.

Verburg, R. M., Nienaber, A. M., Searle, R. H., Weibel, A., Den Hartog, D. N., \& Rupp, D. E. (2018). The role of organizational control systems in employees' organizational trust and performance outcomes. Group \& organization management, 43(2), 179-206. https://doi.org/10.1177\%2F1059601117725191.

Wahyuni, E. S., Taufik, T., \& Ratnawati, V. (2016). Pengaruh budaya organisasi, locus of control, stres kerja terhadap kinerja aparat pemerintah daerah dan kepuasan kerja sebagai variabel intervening (Studi empiris pada Pemerintah Kabupaten Bengkalis). Jurnal Manajemen, 20(2), 189-206. http://dx.doi.org/10.24912/jm.v20i2.43.

Wickramasinghe, M. D. N., \& Sajeevani, T. L. (2018). The Impact of Rewards on Retention of Operational Level Employees in Three Apparel Sector Companies in Export Processing Zone in Biyagama, Sri Lanka. Human Resource Management Journal, 6(2). https://doi.org/10.31357/hrmj.v6i2.3587.g2843.

Yeh, H., \& Hong, D. (2012). The mediating effect of organizational commitment on leadership type and job performance. The Journal of Human Resource and Adult Learning, 8(2), 50. 
*) Sitti Rizki Mulyani, Department of Management, University of Putra Indonesia YPTK, Padang, Indonesia (Email: sittirizkimulyani@ upiyptk.ac.id)

**) Marta Widian Sari, Department of Management, University of Putra Indonesia YPTK, Padang, Indonesia (Email: martawidiansari@upiyptk.ac.id)

***) Vivi Nila Sari, Department of Management, University of Putra Indonesia YPTK, Padang, Indonesia (Email: vivinilasari@ upiyptk.ac.id)

****) Winda Tawakalni, Department of Management, University of Putra Indonesia YPTK, Padang, Indonesia (Email: winda.tawakalni040610@gmail.com)

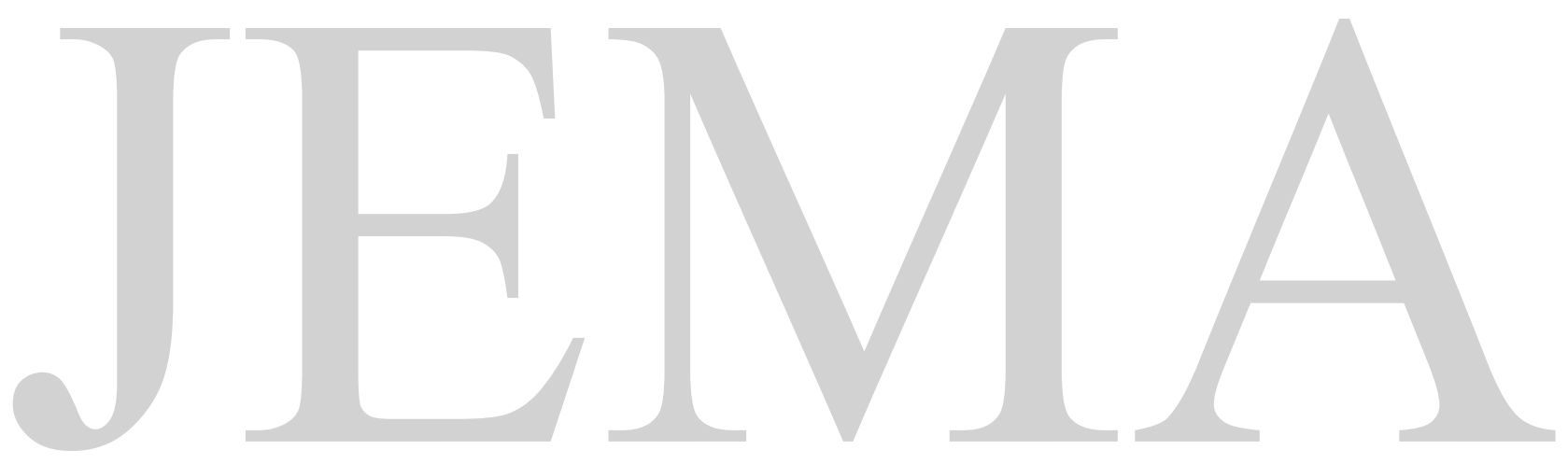

